\title{
EFFECTS OF PERSONAL TRAITS ON GENERATION Y CONSUMERS' ATTITUDES TOWARD THE USE OF MOBILE DEVICES FOR COMMUNICATION AND COMMERCE
}

\author{
Jihyun Kim \\ Department of Apparel, Housing, and \\ Resource Management \\ Virginia Polytechnic Institute and State University \\ Blacksburg, VA, USA
}

\author{
Kim H. Y. Hahn \\ The Fashion School \\ Kent State University \\ Kent, $\mathrm{OH}$ \\ USA
}

\begin{abstract}
The purpose of this study was to investigate the effects of young adult consumers' personal traits (high-tech involvement, experiment proclivity, and fashion/brand leadership) on their perceptions of and attitudes toward using mobile devices for communications and commerce. The integrated stimulus-organism-responses paradigm (Fiore \& Kim, 2007) served as the overarching framework, combining the uses and gratifications theory (Blumler \& Katz, 1974) and the extended technology acceptance model (Kim, Ma, \& Park, 2009). A convenience sample of 504 college students in $2 U$. S. universities provided usable responses to our survey. Causal modeling analysis results showed that personal trait variables had significant impacts on the perceived ease of use, usefulness, and enjoyment, and attitudes toward mobile communication and mobile commerce. Findings also suggested that three perception variables positively influenced attitudes toward using mobile devices for communication as well as for commerce. This study provides empirical evidence of the potential of mobile commerce among young adult consumers.
\end{abstract}

Keywords: mobile technology, personal traits, Generation Y, fashion industry.

\section{INTRODUCTION}

Mobile technology has evolved into a new, fast-growing marketing communication tool. Via technology, consumers access the Internet wirelessly to search for and research information, products, and services from anywhere and at any time (Ktoridou, Epaminondas, \& Kaufmann, 2008). Mobile commerce (hereafter m-commerce) is defined as next-generation e-commerce in which any monetary transactions, such as shopping, banking, purchasing mobile phone services, and investing, occur using mobile devices (Ko, Kim, \& Lee, 2009). By the end of 2011, it was estimated that there were approximately 5.98 billion mobile subscriptions worldwide, which was

(C) 2012 Jihyun Kim \& Kim H. Y. Hahn, and the Agora Center, University of Jyväskylä URN:NBN:fi:jyu-201211203032 
equivalent to $87 \%$ of the world's population. This was a substantial increase from 5.4 billion in 2010, and 4.7 billion subscriptions in 2009. Nearly a billion and a half mobile subscribers lived in the developed countries, which implied the fact that the mobile subscription industry in these countries was quite saturated. On the other hand, the 4.52 billion subscribers in the developing countries results in a $79 \%$ penetration rate, which signals potential growth in these regions. (International Telecommunication Union, 2011). Further, it was estimated that m-commerce revenues in the US alone were expected to hit US\$1 billion in 2012, and mobile advertising growing to US $\$ 38$ billion by 2015 (Favell, 2011). According to Oracle's (2011) mobile trends report, $48 \%$ of consumers across all age groups utilize mobile devices on a wireless Internet network to assist in activities ranging from researching or browsing products and/or services on retailers' Web sites to scanning barcodes of merchandise for prices.

Understanding the Gen Y consumer segment is crucial for mobile technology-related industries due to its spending power and heavy usage of mobile devices and services. The consumers of this segment were born between 1980 and 1994, and thus comprise the current young adult population. This segment exhibited an annual expenditure of US $\$ 187$ billion in 2010. Gen Y consumers are known to be early adopters of new technology and heavy users of the Internet (Cross-Bystrom, 2010). According to Adweek (2012), about 38\% of the total U.S. adult population own smart phones, while more than half of Gen Y consumers own them (58\%, about 40.6 million), followed by Gen X $(49 \%)^{1}$ and Gen Z (47\%). In contrast, less than a third of young baby boomers (29\%), a fifth of old baby boomers (19\%), and only $9 \%$ of the GI generation own smart phones. Gen Y consumers outnumbered all other age groups regarding mobile (voice) minutes used, text messages sent/received, and wireless data transmitted (Lenhart, Ling, Campbell, \& Purcell, 2010).

According to Totten, Lipscomb, Cook, and Lesch (2005), the younger generations, such as Gen Y consumers, often use mobile phones as a medium of self-expression and individuality by downloading unique ring tones, screensavers, and message tones onto their phones. For Gen Y consumers, mobile phones are also used as an important means to stay connected with peers and family through social media sites (Kolsaker \& Drakatos, 2009), as well as to extend existing social relationships (Pertierra, 2005). Because Gen Y consumers appear to be in the mainstream of mobile data service users in the US, it is crucial to examine the relationships between their personal traits and beliefs about and attitudes toward communication and commerce using mobile devices.

A recent study revealed that Gen $\mathrm{Y}$ consumers who perceive mobile services as providing emotional value have more satisfaction with the service, which in turn leads to the loyalty intention regarding those mobile services (Kumar \& Lim, 2008). Currently, mcommerce has much potential to grow in the US in many different industries, including the fashion industry. There are, however, only a few studies (e.g., Kim, Ma, \& Park, 2009) regarding the young adult consumer's attitude toward m-commerce and their willingness to adopt $\mathrm{m}$-commerce. Because mobile devices are becoming an important part of young adult consumers' lifestyles (McGuigan, 2005), the consumers' personal traits may influence their behavior regarding mobile devices.

Considering innovative and conspicuous nature of mobile devices in the mobile commerce setting (Kim et al., 2009), we chose three personal trait variables, high-tech involvement, experiment proclivity, and fashion/brand leadership. Thus, the purpose of this study was to examine the effects of these personal trait variables on Gen Y consumers' 
attitudes toward using mobile devices for communication as well as for commerce purposes. The integrated stimulus-organism-responses paradigm (Fiore \& Kim, 2007) served as the overarching framework for this study, combining the extended technology acceptance model (Kim et al., 2009) and the uses and gratifications theory (Blumler \& Katz, 1974). The significance of this study lies in two areas. First, it attempts to offer an integrated theoretical framework to understand contemporary young adult consumers' perceptions of and attitudes toward using mobile devices by synthesizing three theories from various fields, specifically marketing, environmental psychology, and communication. Second, this study investigates how three different personal trait variables (high-tech involvement, experiment proclivity, and fashion/brand leadership) play roles in the consumers' perceptions of and attitude toward mobile communication and toward m-commerce.

\section{THEORETICAL FRAMEWORKS}

Because young adult consumers have adopted wireless Internet technology quickly, it has become urgent to better understand their shopping experiences in today's technologically advanced marketplace. Two theoretical perspectives, the technology acceptance model (TAM) and the uses and gratifications theory (UGT), have been applied extensively in the study of consumer behavior related to the adoption and use of technology (Chua, Goh, \& Lee, 2012; Gao, Sultan, \& Rohm, 2010; Stafford, Stafford, \& Schkade, 2004). For instance, a recent study by Kim et al. (2009) provided empirical evidence supporting the integration of TAM (Davis, 1989) and the theory of reasoned action (Fishbein \& Ajzen, 1975) in the mobile communication context. In this study, we adopt Fiore and Kim's (2007) integrated stimulusorganism-responses (S-O-R) model to serve as a grounding framework to combine and expand UGT and the extended TAM model by Kim et al. (2009). This is done by incorporating and examining the effects of high-tech involvement, experiment proclivity, and fashion/brand leadership as personal trait variables on young consumers' perceptions of and attitudes toward using mobile devices for communications and commerce.

\section{Stimulus-Organism-Response (S-O-R) Model}

Since the introduction of Holbrook and Hirschman's (1982) ground-breaking work on the nature and mechanism of experiential consumption-consumers' hedonic responses during shopping and usage experiences-researchers have studied extensively the effects of experiential consumption on consumer responses. Based on an in-depth literature review in environmental psychology, Fiore and Kim (2007) presented an integrated conceptual model that combines both the hedonic experience-related consciousness-emotion-value model and the utilitarian experience-related cognition-affect-behavior model under the paradigm of the $\mathrm{S}-\mathrm{O}-\mathrm{R}$ model. Stimulus is defined as an element in the shopping environment that potentially affects the consumers' cognitive/consciousness and affective/emotional processes (Fiore \& Kim, 2007). According to Fiore and Kim, person-environment variables, such as personal traits, demographic characteristics, and market segments, serve as moderators influencing the strength and direction of the relationships between the stimulus (the shopping environment) and consumers' responses (attitudes and behaviors) to the shopping environment. They also 
noted that the organism, which includes the individual's consciousness, emotion, and value variables along with the cognition and affect variables, mediates the processes between the stimulus and consumers' responses. In the present study, therefore, we examined various personal trait variables that pertain to mobile shopping environments that may affect consumers' responses toward mobile communication and/or toward m-commerce.

The personal trait variables studied in the current research are high-tech involvement, experiment proclivity, and fashion/brand leadership. Examining these personal traits is also theoretically grounded on UGT (Blumler \& Katz, 1974), which has been used to explain the role of personal motive related to consumer choice of a new communication medium (Chua et al., 2012; Gao et al., 2010; Stafford et al., 2004).

\section{Uses and Gratifications Theory (UGT)}

The UGT stemmed from mass communications research as a paradigm to understand media users' motives to seek out a media source that fulfills specific gratifications (Blumler \& Katz, 1974). The UGT is considered to be one of the most appropriate theoretical frameworks to predict factors related to consumer choice of media (Chua et al., 2012; Gao et al., 2010). The UGT has been used in the study of consumers' adoption of different media, including technologies, software services, and mobile services, and to explain how users proactively search for the optimum medium that will not only meet the given basic needs but also enhance knowledge and social and psychological needs (Chua et al., 2012; Gao et al., 2010; Leung, 2001; Leung \& Wei, 2000; Katz \& Blumler, 1974; Stafford et al., 2004). Previous studies have demonstrated that nonutilitarian gratifications, such as sociability, symbolizing one's status, and fashionability, are very prominent for mobile uses (Leung, 2001; Leung \& Wei, 2000; Thorbjornsen, Pedersen, \& Nysveen, 2007). For example, related to an individual's instant messaging service, Leung (2001) found that usage was defined by seven gratification factors: relaxation, entertainment, fashion, inclusion, affection, sociability, and escape. In a study of mobile phone use, Leung and Wei (2000) also identified several perceived gratification factors, including affection/sociability, entertainment, instrumentality, psychological reassurance, fashion/status mobility, and immediate access. In a study that examined users' motivation on Internet use, Stafford et al. (2004) identified three major gratifications: content, process, and the social. Content gratifications concern the information and technology application hosted by the mobile service, process gratifications concern the actual use of the mobile technology, which involves high-tech involvement and experiment proclivity, while social gratifications are related to the mobile use for interpersonal communication, status, and thus fashion in general, including fashion/brand leadership. Although Stafford et al.'s (2004) study was based on Internet use, we believe similar gratifications can be identified for mobile use. Therefore, we draw on Stafford et al.'s three gratification factors for investigating three personal trait variables: high-tech involvement, experiment proclivity, and fashion/brand leadership.

\section{Extended Technology Acceptance Model (TAM)}

TAM (Davis, 1989), which originated from the theory of reasoned action (TRA; Ajzen \& Fishbein, 1980; Fishbein \& Ajzen, 1975) and was tailored for the field of information system management, presented perceived usefulness and perceived ease of use as attitudinal 
determinants to explain relationships among attitudes, intention to use, and actual application usage of a specific technology application system. A number of studies support the relationships depicted by the TAM (e.g., Kwon \& Chidambaram, 2000; Nysveen, Pedersen, \& Thorbjornsen, 2005a, 2005b; Pagani, 2004; Venkatesh, Morris, Davis, \& Davis, 2003). Integrating TAM, TRA, and the media dependency theory (Ball-Rokeach \& DeFleur, 1976), Kim et al. (2009) proposed and empirically tested an extended TAM model in mobile communication and m-commerce settings. They found positive relationships among consumers' perceptions of the ease of mobile device use, usefulness of mobile devices, and enjoyment using mobile devices in predicting adoption of mobile communication and $\mathrm{m}$-commerce for the fashion industry.

This current study extends the Kim et al. (2009) study by examining the effect of personal trait variables on consumers' attitudes toward the adoption of mobile technology for fashion goods. In this study, various personal traits (high-tech involvement, experiment proclivity, and fashion/brand leadership) were examined as predictors of perceived ease of use, perceived usefulness, and perceived enjoyment using mobile devices. Based on the synthesis of the adopted theoretical frameworks, we proposed the conceptual model (see Figure 1) to be empirically examined in the present study. Subsequent literature review for hypotheses development follows.

\section{LITERATURE REVIEW}

\section{Consumer Behavior in M-commerce}

The significant growth in mobile device usage has resulted in the increasing execution of mobile advertisements for products and services and, in turn, mobile networking has become an efficient and effective channel of marketing communication (Tsang, Ho, \& Liang, 2004). However, the results of this effective channel cannot be successful without positive consumer attitudes toward the channel and/or advertisement itself. Consumers' attitudes toward mcommerce have been studied by comparing consumers in the US and other countries (e.g., Altuna \& Konuk, 2009; Shen \& Chen, 2008). Various antecedents affecting consumers' attitudes toward m-commerce were examined in previous studies. Jun and Lee (2007) found that characteristics of mobile technology, such as mobility, convenience, and multimedia service, were positively related to attitudes toward mobile advertising. Phau and Teah (2009) studied young consumers' motives for using short message services (SMS) and found that convenience and economical benefits significantly influenced SMS usage frequency. In addition, Nysveen et al. (2005a, 2005b) showed that perceived enjoyment, perceived usefulness, and perceived expressiveness had strong overall impacts on consumers' intentions to use mobile services. They also found that perceived usefulness was a general antecedent for consumers' intentions to use various kinds of mobile services, while perceived enjoyment was a particularly important driver for using experiential services such as communication and gaming services. Furthermore, other studies have examined how mobile marketing influences the consumer decision-making process and shopping experience. For example, Karaatli, Ma, and Suntornpithug (2010) studied mobile services' impact on the overall shopping experience of the consumer and at different stages of the consumer decision-making process. They found that most of the participants believed that mobile services can potentially improve the various 


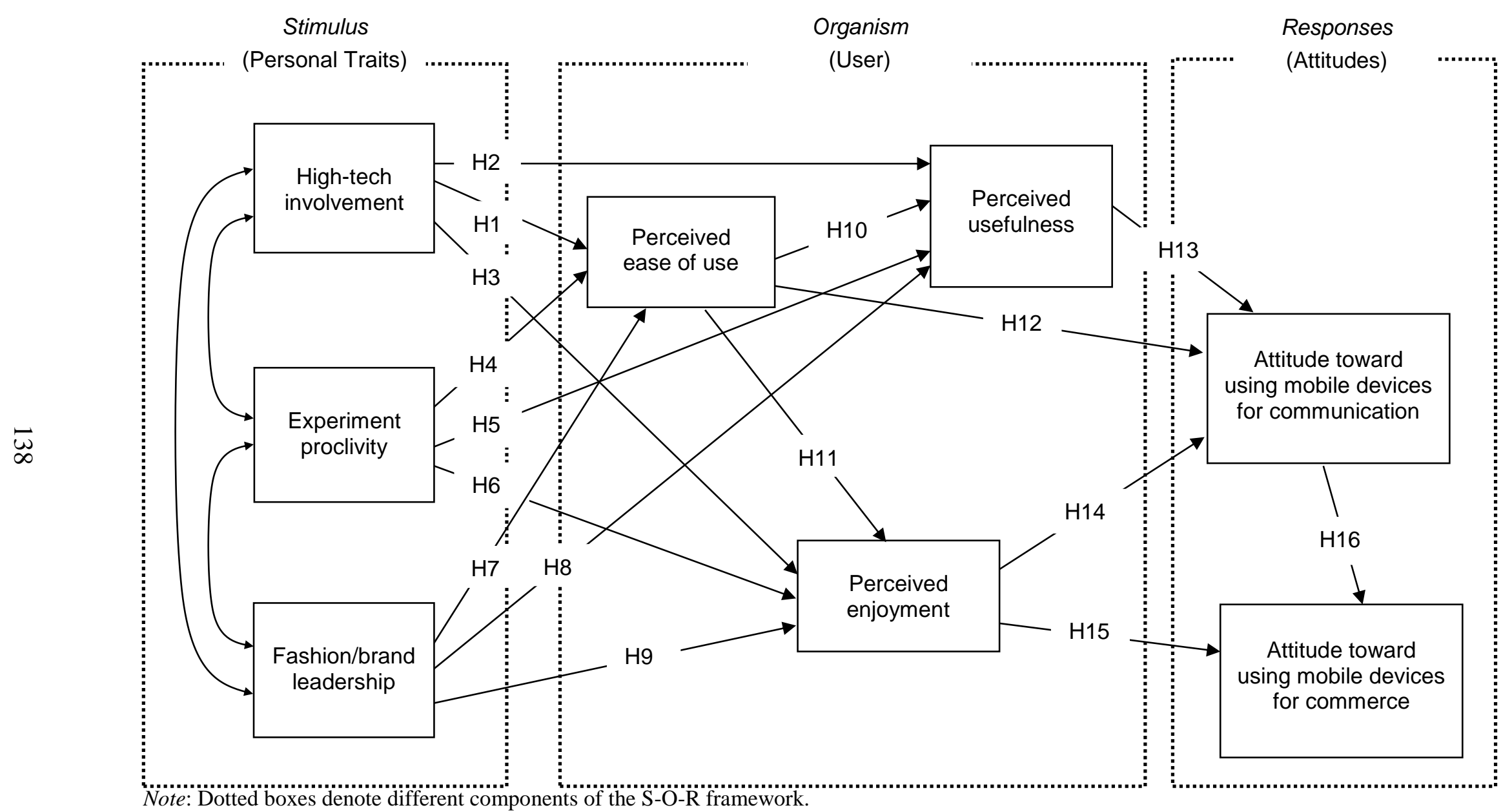

Figure 1. Proposed conceptual model exhibiting relationships among variables. 
aspects of the shopping experience. On the contrary, Maity (2010) examined consumer decision-making experiences across three channels-m-commerce, e-commerce, and instore - and found negative responses to consumer decision-making in the m-commerce setting. This finding was explained by the cognitive cost/sacrifice associated with undertaking decisionmaking in an m-commerce setting: Most participants complained of experiencing physical and emotional stress when using $\mathrm{m}$-commerce as a new retail channel.

\section{High-Tech Involvement and Experiment Proclivity}

A few studies have explored the antecedents of TAM's perception variables, particularly regarding the adoption of $\mathrm{m}$-commerce. One stream examined the relationships between consumers' involvement with advanced technology, such as mobile technology, and their attitudes toward and/or adoption of m-commerce (e.g., Altuna \& Konuk, 2009; Jayasingh \& Eze, 2009). In this paper, we focus on individuals' high-tech involvement as an explanatory and predictive variable for consumers' attitudes toward using mobile devices for communication as well as for commerce. Goldsmith and Hofacker (1992) argued that domainspecific innovation provides a deeper explanation of an individual's innovativeness and is highly associated with one's adoption of new products. In the literature, domain-specific innovativeness has been studied as a significant predictor of consumers' adoption of innovations (e.g., Goldsmith \& Hofacker, 1992; Hirunyawipada \& Paswan, 2006). For instance, Agarwal and Prasad (1998) added a new construct to the TAM called personal innovativeness in information technology, defined as the willingness of an individual to try out any new information technology. Research studies confirm that individuals with higher personal innovativeness are expected to develop more positive beliefs about the use of new technology (e.g., perceived usefulness, perceived ease of use, perceived enjoyment; Agarwal \& Karahanna, 2000; Lewis, Agarwal, \& Sambamurthy, 2003; Lu, Yao, \& Yu, 2005). A recent study by Khare, Singh, and Khare (2010) also found that individuals' innovativeness among the Gen Y segment was a major determinant of online shopping in India. Based on previous literature in domain-specific innovativeness, e-commerce, and $\mathrm{m}$-commerce, we anticipate that we may find positive relationships between individuals' high-tech involvement and perceptions of using mobile devices for communication. Therefore, we hypothesize the following:

H1: High-tech involvement has a positive impact on perceived ease of using mobile devices for communication.

$\mathrm{H} 2$ : High-tech involvement has a positive impact on perceived usefulness of the devices for communication.

H3: High-tech involvement has a positive impact on perceived enjoyment of using the devices for communication.

In previous studies, researchers asserted the need for modifying and extending TAM to be more suitable in the mobile technology context (e.g., Jayasingh \& Eze, 2009). These researchers pointed out that although TAM has been supported with its applications and validations through numerous studies, it does not account for the possibility of influence from social and personal control factors. Venkatesh and Davis (2000) found that computer self-efficacy and objective usability are important antecedents influenced by individual experiences with the system. In the present study, we define the individual's experiment proclivity as one's personal trait and 
inclination toward the new technology/environment where one possesses less reservation and more adapting, as compared to those who are reluctant to use new technology. Thus, they may find using mobile devices easier, more useful, and more fun as compared to their counterparts. For that reason, we hypothesize that individuals' proclivity toward conducting experiments or the experiments themselves may enhance perceptions regarding the use of mobile devices as easy and enjoyable, as well as useful for communication and commerce:

H4: Experiment proclivity has a positive impact on perceived ease of using mobile devices for communication.

H5: Experiment proclivity has a positive impact on perceived usefulness of the devices for communication.

H6: Experiment proclivity has a positive impact on perceived enjoyment of using the devices for communication.

\section{Fashion/Brand Leadership}

In this study, we operationally define fashion/brand leadership as not only one's involvement in and knowledge about fashion but also one's level of influence over peers in regards to selecting fashion products and brands related to being fashionable. Previous studies show that consumers' involvement affects their level of attention, information processing, comprehension, decision making, and response to advertising (Celsi \& Olson, 1988; Isomursu, Isomursu, \& Leinonen, 2006; Maheswaren \& Meyers-Levy, 1990). Hoffman and Novak (1996) found that highly involved consumers would pay greater attention to relevant Web sites, compared to less involved ones. Balabanis and Reynolds (2001) found a significant relationship between consumer involvement and consumer attitude toward online shopping. In addition, it has been proven that social influences have an important impact as one of the antecedent constructs to explain the TAM model (Venkatesh \& Davis, 2000). Sproles (1979, cited in Miller, McIntyre, \& Mantrala, 1993, p. 143) defined fashion as "a way of behaving that is temporarily adopted by a discernible proportion of members of a social group because that chosen behavior is perceived to be socially appropriate for the time and situation." Such individuals closely monitor what is considered as fashionable in the given period and place and spend substantial amounts of time and effort to collect information regarding fashion. In other words, those who considered themselves as fashion leaders are highly involved in the subject matter in our case: fashion. For instance, Kincade, Kim, and Gibson (2010) also found that consumers with a higher level of fashion leadership were highly involved in fashion products and exhibited a higher level of willingness to try on fashion products, compared to counterparts. Their finding implies a positive association among fashion involvement, fashion leadership, and experiential proclivity. Another study found a positive linkage between fashion leadership and use of multiple retail channels (Cho \& Workman, 2011). Their finding may be explained by the consumer's use of mobile devices as fashion statement. For instance, when a brand new mobile device (e.g., iPhone) is launched, fashion leaders consider it fashionable and innovative to acquire the newly launched mobile device. According to Totten and his colleagues (2005), Gen Y consumers tend to view their mobile phones as a means for self-expression. Therefore, we anticipate that the self-expressive nature of 
mobile device uses in public would influence the perceptions of mobile communication as easy, useful, and enjoyable. Based on the previous findings, we hypothesize the following:

H7: Fashion/brand leadership has a positive impact on perceived ease of using mobile devices for communication.

H8: Fashion/brand leadership has a positive impact on perceived usefulness of the devices for communication.

H9: Fashion/brand leadership has a positive impact on perceived enjoyment of using the devices for communication.

\section{TAM Variables as Predictors of Attitudes toward Mobile Communication and toward M-Commerce}

A number of studies have already empirically supported the relationships among perceived ease of use, usefulness, and enjoyment in the context of adoption of mobile technology (e.g., Kwon \& Chidambaram, 2000; Kim et al., 2009; Nysveen et al., 2005a, 2005b). Previous studies showed positive and direct relationships among those variables. Kim et al. (2009) found that perceived ease of use, subjective norms, perceived usefulness, and perceived enjoyment were significant factors influencing consumers' attitudes toward mobile communication and toward m-commerce, which in turn led to their behavioral intention to use m-commerce technology for the purposes of searching for and purchasing fashion products. Therefore, we propose the following:

H10: Perceived ease of using mobile devices for communication has a positive effect on the perceived usefulness of mobile devices for communication.

H11: Perceived ease of using mobile devices for communication has a positive effect on the perceived enjoyment of using mobile devices for communication.

Perceived ease of use, one of the main structural variables of the TAM model, refers to a user's belief that using a particular system is without difficulty and effort (Davis, 1989). Perceived ease of use has been investigated as an important factor in understanding acceptance of information technology (Al-Gahtani \& King, 1999), the wireless Internet through mobile devices (Lu et al., 2005), e-commerce (Jiang, Hsu, Klein, \& Lin, 2000), and m-commerce (Kwon \& Chidambaram, 2000; Kim et al., 2009; Nysveen et al., 2005a, 2005b). In previous studies, the effect of perceived ease of use on attitudes is considered an indirect effect mediated by perceived usefulness. However, recent studies claimed the direct influence of ease of use on attitude toward accepting the technology (Chiu, Huang, \& Yen, 2010; Yu \& Tao, 2009). Therefore, we hypothesize the following:

H12: Perceived ease of using mobile devices for communication has a positive impact on the attitude toward using mobile devices for communication.

Perceived usefulness refers to users' beliefs that using a particular system may improve their performances (Sadia, 2011). In the fashion retailing industry, it is critical to deliver contemporary trends to consumers in a timely manner due to the inherent nature of the goods, especially for fast fashion (Byun \& Sternquist, 2011). A useful Website should provide all possible information, especially the tracking information of specific products. For instance, 
Park and Kim (2007) showed that time-related information, such as stock availability and time for shipping/handling of the ordered items, influences consumers' perceptions of the time-related risks of and attitudes toward online shopping. M-commerce extends e-commerce by using the wireless network. Therefore, the influence of perceived usefulness will be an important factor to investigate regarding users' attitudes toward fashion-related mobile communication and m-commerce. In addition, previous studies have already demonstrated that perceived usefulness was one of the crucial factors influencing the adoption or acceptance of m-commerce services (e.g., Huei, 2004; Mariga, 2003). Recently, Kim et al. (2009) and Yaseen and Zayad (2010) provided additional empirical evidence to this relationship in the $\mathrm{m}$-commerce context. Therefore, we propose the following:

H13: Perceived usefulness of using mobile devices for communication has a positive impact on the attitude toward using mobile devices for communication.

Literature in e-commerce with image interactive technology showed that consumers' emotional pleasures and/or affect acquired in the online shopping environment influenced consumers' attitudes toward online shopping (e.g., Childers, Carr, Peck, \& Carson, 2001; Fiore, Jin, \& Kim, 2005; Kim, Fiore, \& Lee, 2007). The importance of perceived enjoyment has been emphasized by van der Heijden (2004), who claimed that perceived enjoyment dominated perceived usefulness in influencing the adoption behavior of hedonic information systems. Gentry and Calantone (2002) demonstrated that perceived enjoyment and perceived usefulness significantly explained consumer attitudes toward technology in a variety of contexts, including e-commerce. Kim, Park, and Oh (2008) also showed in their study that perceived enjoyment, perceived monetary value, perceived usefulness, and perceived ease of use were four major factors facilitating the adoption of SMS in South Korea. Based on a literature review related to perceived enjoyment, we hypothesize the following:

H14: Perceived enjoyment of using mobile devices for communication has a positive impact on the attitude toward using mobile devices for communication.

H15: Perceived enjoyment of using mobile devices for communication has a positive impact on the attitude toward using the devices for m-commerce.

\section{Attitude Shifts Among the Retail Channels}

Using the media dependency theory (Ball-Rokeach \& DeFleur, 1976), Kim and Park (2005) illustrated a significant attitudinal shift from a traditional brick-and-mortar retailer to an online version of the retailer. Their study was one of the first empirical attempts to establish the theoretical argument that consumers' attitudes toward the new and/or technologically advanced retail channel is based on their present attitudes toward the traditional channel of that retailer. Based on this finding, Kim and her colleagues (2009) proposed a positive causal linkage between the attitude toward using mobile devices for communication purposes and the attitude toward using mobile devices for commerce. Kim et al. (2009) empirically demonstrated that consumers' attitudinal shifts occurred in the mobile technology context. Similarly, Bigné, Ruiz, and Sanz (2007) found that the frequency and the duration of mobile device use influenced the frequency of using m-commerce. Thus, based on the previous literature, we propose the following: 
H16: The attitude toward using mobile devices for communication purposes has a positive impact on the attitude toward using the devices for m-commerce.

\section{METHOD}

\section{Sample and Data Collection}

We obtained a total of 504 usable responses from college students who reported existing subscriptions to mobile services on their devices. Respondents were recruited from six academic courses in a mix of general education and fashion merchandising disciplines in two large U.S. universities, one in the Midwest region and the other in the Southeast Coastal region, using a nonrepresentative convenience sampling technique. Students who volunteered for participation received extra course credit as an incentive during a 2-month period in spring 2011. For this study, we adopted a college student sample because the majority of the students represent Gen Y. This generational segment is critical for examining perception and evaluation of mobile uses due to their extensive usage of mobile devices (Burns, 2005; Ehret, 2011). For instance, they often use mobile technology to stay connected with family and friends by checking e-mails, sending text messages, or updating their statuses on social media sites, as well as applying the technology to diverse activities for entertainment (Cross-Bystrom, 2010; Totten et al., 2005).

\section{Instruments}

To measure an individual's personal traits, we researchers adopted scales from previous literature, as shown in Table 1. To measure high-tech involvement, six items from Goldsmith and Hofacker's (1992) domain-specific innovativeness scale and two items from Dickerson and Gentry (1983) were adopted and modified to suit the high-tech product category. To measure the experiment proclivity, three items were adopted from Joseph and Vyas's (1984) open processing scale. To measure fashion/brand leadership, we adopted three items from Lumpkin (1985) and two items from Hawes and Lumpkin (1984). To measure three perception constructs in the TAM - perceived ease of use, perceived usefulness, and perceived enjoyment - regarding mobile device uses for communication, we adopted Childers et al.'s (2001) scales. All items were measured on a five-point Likert scale from 1, strongly disagree, to 5, strongly agree. All TAM scales were modified to suit the mobile communication context (See Table 2).

A six-item attitude scale (e.g., bad-good, unfavorable-favorable, dislike-like) developed by Stayman and Batra (1991) was used for measuring both attitude toward mobile communication and attitude toward m-commerce on a five-point semantic differential scale. The preface, "Using a cell phone for communication with others would be..." was used for attitude toward mobile communication, whereas "purchasing music, phone ring tones, wallpapers, etc., using cell phone would be..." was used for attitude toward m-commerce. We also gathered participants' demographic information including age, sex, ethnicity, and disposable income. Prior to distribution, four graduate research assistants and two faculty members pilot-tested the questionnaire to ensure the clarity of item wording and appropriateness of modified items in the mobile usage context. 
Table 1. Exploratory Factor Analysis of Personal Trait Variables.

\begin{tabular}{|c|c|c|c|c|}
\hline Factor dimensions and items & $\begin{array}{l}\text { Factor } \\
\text { loadings }\end{array}$ & $\begin{array}{l}\text { Total variance } \\
\text { explained (\%) }\end{array}$ & $\begin{array}{l}\text { Eigen } \\
\text { values }\end{array}$ & $\begin{array}{l}\text { Cronbach's } \\
\text { alpha }\end{array}$ \\
\hline $\begin{array}{l}\text { Factor 1: High-tech Involvement } \\
\text { - High-tech products bring me comfort and convenience. } \\
\text { - In general, I am among the first in my circle of friends to buy a } \\
\text { new high-tech product (e.g., MP3, PDA, cell phone, digital } \\
\text { camera, etc.) when it appears. } \\
\text { - If I heard that a new high-tech product was available in the } \\
\text { store, I would be interested enough to buy it. } \\
\text { - Compared to my friends, I own a lot of high-tech products. } \\
\text { - In general, I am the first in my circle of friends to know the } \\
\text { titles/brands of the latest high-tech product. } \\
\text { - I will buy a new high-tech product if I haven't heard/tried it yet. } \\
\text { - I like to buy a high-tech product before other people do. }\end{array}$ & $\begin{array}{l}.55 \\
.87 \\
.83 \\
\\
.87 \\
.85 \\
.70 \\
.86\end{array}$ & 23.78 & 4.81 & .92 \\
\hline $\begin{array}{l}\text { Factor 2: Experiment Proclivity } \\
\text { - I like to experiment with new ways of doing things. } \\
\text { - I like to fool around with new ideas even if they turn out to be a } \\
\text { waste of time. } \\
\text { - I like to try new and different things. }\end{array}$ & $\begin{array}{l}.83 \\
.82 \\
.80\end{array}$ & 11.17 & 2.05 & .81 \\
\hline $\begin{array}{l}\text { Factor 3: Fashion/Brand Leadership } \\
\text { - I closely monitor fashionable trends. } \\
\text { - I enjoy pursuing something fashionable and exciting. } \\
\text { - Products and brands are central topics of my conversation } \\
\text { with friends. }\end{array}$ & $\begin{array}{l}.88 \\
.87 \\
.63\end{array}$ & 10.01 & 1.79 & .81 \\
\hline Total variance explained & \multicolumn{4}{|c|}{$44.96 \%$} \\
\hline
\end{tabular}

Table 2. Exploratory Factor Analysis of the TAM Perception Variables.

\begin{tabular}{|c|c|c|c|c|}
\hline Factor dimensions and items & $\begin{array}{l}\text { Factor } \\
\text { loadings }\end{array}$ & $\begin{array}{l}\text { Total variance } \\
\text { explained (\%) }\end{array}$ & $\begin{array}{c}\text { Eigen } \\
\text { values }\end{array}$ & $\begin{array}{c}\text { Cronbach's } \\
\text { alpha }\end{array}$ \\
\hline $\begin{array}{l}\text { Perceived usefulness of mobile devices } \\
\text { Communication using cell phone is: } \\
\text { - useless-useful } \\
\text { - worthless-valuable } \\
\text { - unhelpful-helpful } \\
\text { - not functional-functional } \\
\text { - time wasting-time saving }\end{array}$ & $\begin{array}{l}.83 \\
.83 \\
.86 \\
.86 \\
.74\end{array}$ & 49.70 & 7.95 & .93 \\
\hline $\begin{array}{l}\text { Perceived enjoyment of using mobile devices } \\
\text { Communication using cell phone is: } \\
\text { - not entertaining-entertaining } \\
\text { - not enjoyable-enjoyable } \\
\text { - boring-interesting } \\
\text { - not fun-fun } \\
\text { - unexciting-exciting }\end{array}$ & $\begin{array}{l}.80 \\
.83 \\
.86 \\
.87 \\
.88\end{array}$ & 17.98 & 2.88 & .94 \\
\hline $\begin{array}{l}\text { Perceived ease of using mobile devices } \\
\text { Use of cell phone: } \\
\text { - is clear and understandable } \\
\text { - does not require a lot of mental effort } \\
\text { - is easy } \\
\text { - allows me to communicate in the way I want to } \\
\text { - is easy to learn }\end{array}$ & $\begin{array}{l}.76 \\
.87 \\
.87 \\
.77 \\
.82\end{array}$ & 9.62 & 1.54 & .89 \\
\hline Total variance explained & \multicolumn{4}{|c|}{$77.30 \%$} \\
\hline
\end{tabular}




\section{FINDINGS}

\section{Sample Description}

Slightly more than one half of our respondents were female $(n=266,52.5 \%)$. Respondents ranged between 18 and 26 years of age at the time of the data collection. Most respondents (94.6\%) fell in the age range between 18 and 23 years, with almost three quarters being aged 20 to 22 years $(74.6 \%)$. The majority were Caucasians $(87.9 \%)$, followed by Asian Americans (4.6\%), African Americans (2.8\%), and Hispanic Americans (1.2\%). Slightly over $35 \%$ of the respondents reported that they had a monthly discretionary income of less than $\$ 100$, and another 36.5\% had that of between $\$ 100$ and $\$ 299$. Descriptive statistics of the respondents' demographics are shown in Table 3.

\section{Preliminary Analysis}

Exploratory factor analysis using a varimax rotation was conducted to test construct validity of research variables and to determine whether multiple indicators for each research variable

Table 3. Demographics of the Survey Respondents $(N=504)$.

\begin{tabular}{|c|c|c|c|}
\hline Demographics & Categories & Frequency & Percent (\%) \\
\hline \multirow[t]{9}{*}{ Age } & 18 & 22 & 4.4 \\
\hline & 19 & 42 & 8.3 \\
\hline & 20 & 94 & 18.7 \\
\hline & 21 & 161 & 31.9 \\
\hline & 22 & 121 & 24.0 \\
\hline & 23 & 37 & 7.3 \\
\hline & 24 & 15 & 3.0 \\
\hline & 25 & 9 & 1.8 \\
\hline & 26 & 3 & 0.6 \\
\hline \multirow[t]{3}{*}{ Sex } & Male & 226 & 44.8 \\
\hline & Female & 266 & 52.8 \\
\hline & Missing & 12 & 2.4 \\
\hline \multirow[t]{7}{*}{ Ethnicity } & Asian American & 23 & 4.6 \\
\hline & Black or African American & 14 & 2.8 \\
\hline & Latino or Hispanic American & 6 & 1.2 \\
\hline & Native American & 2 & 0.4 \\
\hline & White or Caucasian American & 443 & 87.9 \\
\hline & Other & 12 & 2.4 \\
\hline & Missing & 4 & 0.8 \\
\hline \multirow[t]{2}{*}{ Region } & Midwest & 159 & 31.5 \\
\hline & Southeast coastal & 345 & 68.5 \\
\hline \multirow[t]{7}{*}{ Disposable income } & Less than $\$ 100$ & 185 & 36.7 \\
\hline & $\$ 100$ to $\$ 299$ & 184 & 36.5 \\
\hline & $\$ 300$ to $\$ 499$ & 74 & 14.6 \\
\hline & $\$ 500$ to $\$ 699$ & 24 & 4.8 \\
\hline & $\$ 700$ to $\$ 899$ & 16 & 3.2 \\
\hline & More than $\$ 900$ & 8 & 1.6 \\
\hline & Did not disclose & 13 & 2.6 \\
\hline
\end{tabular}


comprised one factor dimension (Cronbach \& Meehl, 1955). Factor loadings above .55 (Nunnally $\&$ Bernstein, 1994) and less than .30 on other factors (Kline, 2004) were considered evidence for construct validity. Cronbach's alphas of all research constructs were above .81 , indicating good reliabilities of measures (see Tables 1 and 2). Means of summated multiple item variables were used to represent model constructs for testing the proposed model and research hypotheses.

\section{Causal Model Analysis: Hypotheses and Model Testing}

The proposed model consists of three exogenous variables (high-tech involvement, experiment proclivity, and fashion/brand leadership) and five endogenous constructs (perceived ease of use, perceived usefulness, perceived enjoyment, attitude toward using the mobile device for communication, and attitude toward using mobile device for commerce). Descriptive statistics and correlation coefficients among constructs for the model are presented in Table 4.

The path analysis of the causal model was conducted by a maximum-likelihood estimation procedure using AMOS 20.0. To assess the model fit, a chi-square statistic, goodness-of-fit index (GFI), adjusted goodness-of-fit index (AGFI), parsimonious goodnessof-fit index (PGFI), normed fit index (NFI), and root mean square error of approximation (RMSEA) were used. The chi-square test assesses the adequacy of a hypothesized model to reflect variance and covariance of the data. We used Kline (2004) and Schumacker and Lomax (2004) criteria as an indicator of good model fit to the data (GFI >0.95, AGFI >0.90, PGFI $<0.50$, NFI $>0.95$, RMSEA $<0.07$, chi-square $d f<2$ ). For the statistical significance of parameter estimates, $t$-values were used.

Table 4. Descriptive Statistics and Correlation Matrix of the Model Constructs.

\begin{tabular}{|c|c|c|c|c|c|c|c|c|}
\hline Constructs & 1 & 2 & 3 & 4 & 5 & 6 & 7 & 8 \\
\hline 1. High-tech involvement & 1 & & & & & & & \\
\hline 2. Experiment proclivity & $.31^{\star *}$ & 1 & & & & & & \\
\hline $\begin{array}{l}\text { 3. Fashion/Brand } \\
\text { leadership }\end{array}$ & $.43^{* *}$ & $.30^{* *}$ & 1 & & & & & \\
\hline $\begin{array}{l}\text { 4. Perceived ease of using } \\
\text { mobile devices for } \\
\text { communication }\end{array}$ & $.21^{* *}$ & $.21^{* *}$ & $.18^{* *}$ & 1 & & & & \\
\hline $\begin{array}{l}\text { 5. Perceived enjoyment of } \\
\text { using mobile devices for } \\
\text { communication }\end{array}$ & $.12^{* *}$ & $.09^{*}$ & $.23^{* *}$ & $.26^{* *}$ & 1 & & & \\
\hline $\begin{array}{l}\text { 6. Perceived usefulness of } \\
\text { using mobile devices for } \\
\text { communication }\end{array}$ & .07 & $.13^{* *}$ & $.17^{\star *}$ & $.38^{* *}$ & $.62^{* *}$ & 1 & & \\
\hline $\begin{array}{l}\text { 7. Attitude toward using } \\
\text { mobile devices for } \\
\text { communication }\end{array}$ & .08 & $.13^{* *}$ & $.25^{* *}$ & $.42^{* *}$ & $.49^{* *}$ & $.55^{* *}$ & 1 & \\
\hline $\begin{array}{l}\text { 8. Attitude toward using } \\
\text { mobile devices for } \\
\text { commerce }\end{array}$ & $.11^{*}$ & $.10^{*}$ & $.26^{* *}$ & $.10^{*}$ & $.30^{* *}$ & $.23^{* *}$ & $.30^{* *}$ & 1 \\
\hline Mean & 2.70 & 3.78 & 3.10 & 4.35 & 3.85 & 4.39 & 4.31 & 3.07 \\
\hline$S D$ & 0.94 & 0.76 & 1.03 & 0.64 & 0.83 & 0.73 & 0.72 & 0.37 \\
\hline
\end{tabular}


The results of the causal model analysis of the proposed conceptual model revealed a chisquare of 69.88 with 9 degrees of freedom (chi-square/ $d f=7.77 ; p<.01$ ). The GFI was .97 ; AGFI was .87; PGFI was .24; NFI was .76; and RMSEA was .116. The fit indices were not acceptable according to the Kline's (2004) criteria. Thus, we deleted the insignificant paths from the model. Then we revised the model by including two additional causal paths suggested by the modification indices (i.e., fashion/brand leadership to attitudes toward mobile communication as well as toward m-commerce). The causal analysis of this revised model achieved a chi-square of 12.56 with 11 degrees of freedom $(p=0.32)$. The GFI was .99; AGFI was .98; PGFI was .30; NFI was .98; and RMSEA was .017. The fit indices indicate that the revised model fit the data very well and is parsimonious. Figure 2 exhibits the results of testing the revised model, including significant standardized path coefficients and $t$-values for each relationship as well as squared multiple correlations $\left(R^{2}\right)$ for each endogenous construct. The revised model explained a small to large amount of variance in dependent variables, including perceived ease of use $\left(R^{2}=\right.$ $.07)$, perceived usefulness $\left(R^{2}=.15\right)$, perceived enjoyment $\left(R^{2}=.10\right)$, attitude toward mobile communication $\left(R^{2}=.639\right)$, and attitude toward m-commerce $\left(R^{2}=.15\right)$.

Eleven hypotheses received statistical support, while five were rejected. Hypothesis 1, examining the effects of individuals' high-tech involvement on perceived ease of use of mobile devices, was statistically significant (gamma $11=.16, p<.01$ ), while it had no significant impact on perceived usefulness $(\mathrm{H} 2$ : gamma $21=.08, p=.11)$ nor perceived enjoyment $(\mathrm{H} 3$ : gamma $31=.01, p=.86$ ). Hypotheses 4 through 6 , testing the positive effects of individuals' experiment proclivity on perceived ease of use, perceived usefulness, and perceived enjoyment, only received statistical support for its impact on perceived ease of use $\left(\mathrm{H} 4\right.$ : gamma $_{12}=.16, p$ $<.01$ ), while it did not have significant direct effects on perceived usefulness (H5: gamma $22=$ $.04, p=.38$ ) nor perceived enjoyment (H6: gamma $32=.01, p=.84$ ). Hypotheses 7 through 9 proposed a positive and direct influence of fashion/brand leadership on three TAM variables. The findings indicated significant statistical support regarding the influence of fashion/brand leadership on perceived usefulness (H8: gamma $23=.11, p<.01)$ as well as perceived enjoyment (H9: gamma $33=.19, p<.01)$, while not exhibiting its impact on the perceived ease of use (H7: gamma $\left._{13}=.09, p=.08\right)$.

As we proposed, perceived ease of use exhibited positive and direct effects on perceived usefulness, perceived enjoyment, and attitude toward mobile communication (H10: beta $21=.36$, $p<.01 ; \mathrm{H} 11$ : beta $31=.23, p<.01 ; \mathrm{H} 12$ : beta $41=.23, p<.01$ ). Hypothesis 13 , which tested the positive relationship between perceived usefulness on the attitude toward mobile communication, also received statistical support $(\mathrm{H} 13$ : beta $42=.31, p<.01)$. Hypotheses 14 and 15 investigating perceived enjoyment's positive and direct impact on the attitude toward mobile communication as well as toward m-commerce also received statistical support (H14: beta ${ }_{43}=$ $.22, p<.01$; H15: beta $53=.18, p<.01)$. Lastly, Hypothesis 16 proposed that attitude toward mobile communication positively predicts attitude toward m-commerce, and results showed that this positive prediction received statistically significant support $\left(\mathrm{H} 16\right.$ : beta $\left.{ }_{54}=.16, p<.01\right)$.

\section{DISCUSSION}

As mobile technology has become a venue for the next generation of e-commerce (Ktoridou et al., 2008) and an important part of young consumers' lifestyles, it was imperative to 


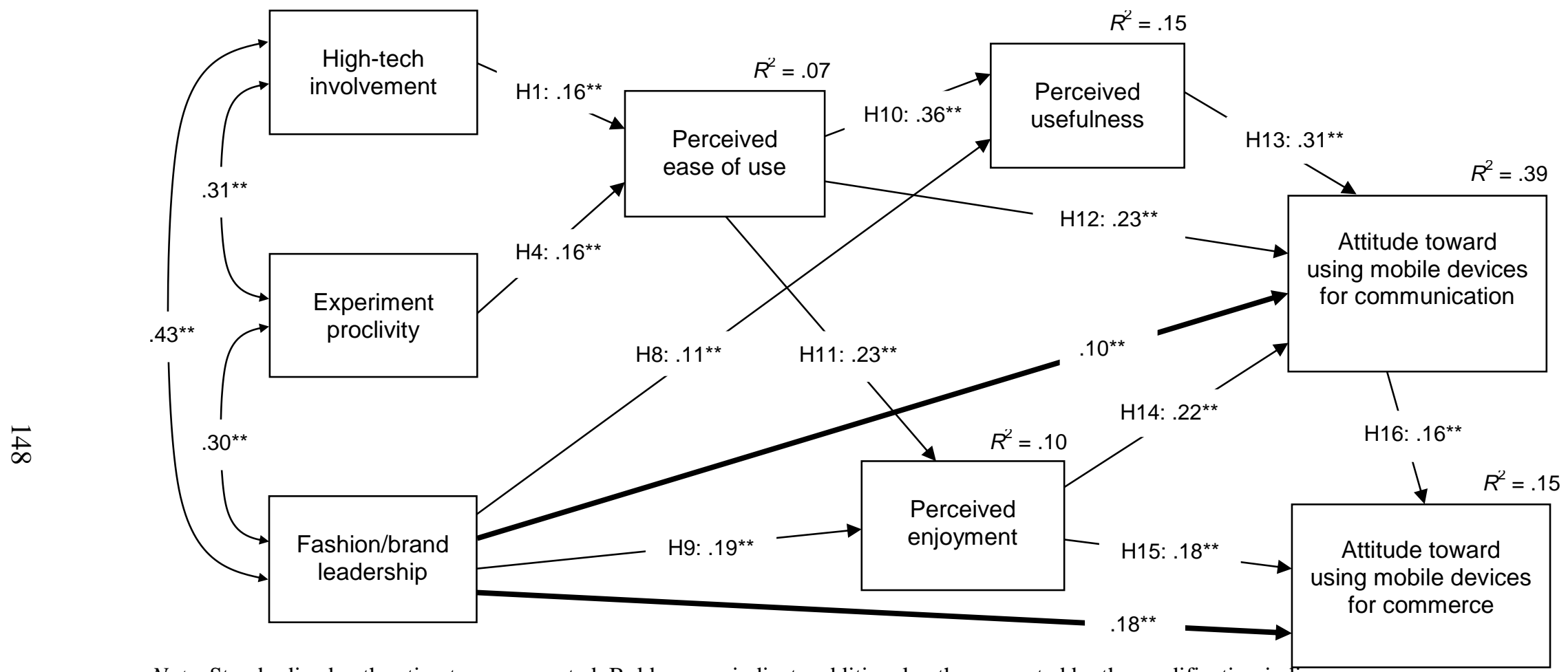

Note: Standardized path estimates are reported. Bold arrows indicate additional paths suggested by the modification indices. $* * p<.01$ using two-tail test

Figure 2. Causal model analysis results of the revised model. 
examine the effect of personal traits on consumer perceptions of using mobile devices as well as attitudes toward mobile communication and toward m-commerce. The present study's findings showed that individuals' high-tech involvement and experiment proclivity were important factors influencing individuals' perceived ease of using mobile devices for communication, although they did not explain perceived usefulness and perceived enjoyment of using the devices for communication. As indicated earlier, perceived ease of use is defined as users' belief that using a particular system is without difficulty and effort (Davis, 1989). Consumers who are already highly involved in technology and who are likely to try new things are most likely to find using mobile devices not difficult. However, those individuals probably have used technological devices other than mobile ones, and would not necessarily find mobile devices more useful and enjoyable than other devices. Another possible explanation may be the mediating role of the perceived ease of use between the personal trait variables and perceived usefulness and perceived enjoyment of using mobile devices. This is consistent with previous findings related to the TAM model that the effect of external variables on attitude is mediated by the perceived ease of use (Venkatesh \& Davis, 2000).

This study revealed that fashion/brand leadership had a positive effect on both perceived enjoyment and perceived usefulness of mobile devices for communication, yet no significant effect on perceived ease of using the devices. This result is consistent with findings of previous studies related to fashion innovativeness: Consumers with higher fashion innovativeness tend to engage more often in experiential shopping that is motivated by a desire for pleasure rather than practical purposes (e.g., Cho \& Workman, 2011; Peck \& Childers, 2003). Thus, those individuals with higher levels of fashion/brand leadership would find mobile devices more enjoyable compared to those with lower levels of fashion/brand leadership. In addition, this finding is in line with the UGT studies that demonstrated the strong influence of nonutilitarian gratifications, including sociability, symbolizing one's status, and fashionability, as very prominent for mobile uses (Leung, 2001; Leung \& Wei, 2000; Thorbjornsen et al., 2007).

In addition to the proposed hypotheses, fashion/brand leadership exhibited a significant and positive impact on the attitude toward using mobile devices for communication as well as the attitude toward using the devices for commerce. Although not anticipated, these results dovetail with recent theory and research on the expressive nature of the mobile devices as a part of the individual self (e.g., Totten et al., 2005). Most smart phones equipped with mobile Internet technology are rather highly priced and designed to exhibit cutting-edge, technologically advanced functions. For instance, the iPhone $4 \mathrm{~s}$ has unique design elements and features that make the device easy to differentiate from other devices. Thus, mobile devices can be used as means of self-expression or developing one's identity (Shtykh et al., 2009; Taylor \& Harper, 2001) by purchasing custom cases. As a result, mobile devices function as visible products that possibly modify the users' projected image in the same manner as fashion products do (Sproles, 1979, in Miller et al., 1993).

Another possible explanation for the positive effect of fashion/brand leadership on attitude toward mobile devices is the young consumers' cultural issues. Whether young consumers already perceive mobile devices as fashionable products or not, using mobile devices has become the most distinctive cultural factor among Gen Y consumers. Thus, leaders in fashion may exhibit even more positive attitudes toward using mobile devices for communication and commerce to reconfirm their leadership in innovativeness toward new things. Therefore, this 
visibility, as well as the quintessential cultural value of using mobile devices, may enhance consumers' attitudes toward mobile devices for communication as well as for commerce.

This study adopted three different behavioral theories, S-O-R, UGT, and extended TAM, to form an integrated theoretical model for understanding the mobile behavior of contemporary young consumers. The findings of this study are consistent with the previous studies (Kim et al., 2009; Kwon \& Chidambaram, 2000; Nysveen et al., 2005a, 2005b; Pagani, 2004) that exhibited direct and positive relationships among three TAM variables: perceived ease, perceived usefulness, and perceived enjoyment of using mobile devices.

Consistent with prior studies (e.g., Kim et al., 2009), all three TAM variables also were found to be significant antecedents of attitudes toward using mobile devices for communication as well as commerce. In addition, the findings showed that the proposed model based on the paradigm of the S-O-R model also exhibited the robustness of the paradigm in the mobile communication and $\mathrm{m}$-commerce context. Personal traits exhibited various direct relationships to the organism (three perception variables), which in turn had a positive impact on the responses (attitudes toward using the mobile devices for communication as well as commerce).

\section{IMPLICATIONS FOR RESEARCH}

Previous research by Kim et al. (2009) provided empirical ground for the causal linkages between attitudes and behavioral intention toward mobile communication and toward $\mathrm{m}$ commerce. Thus, in the present study, we focused on revealing the crucial antecedents of the TAM perception variables, which in turn influenced attitudes toward mobile communication and toward m-commerce. The findings of the present study exhibited the important roles of three personal trait variables - high-tech involvement, experiment proclivity, and fashion/brand leadership - on the consumers' perceptions of and attitudes toward using mobile devices for communication and commerce. Although only some research hypotheses received statistical support, the findings of this study contribute to contemporary research on mobile communication and $\mathrm{m}$-commerce by demonstrating these specific personal traits as antecedents of the three core belief constructs in the TAM-perceived usefulness, perceived enjoyment, and perceived ease of use-in the m-commerce context.

Moreover, the findings of the present study exhibited additional direct relationships explaining the impact of individuals' fashion/brand leadership on attitudes toward using mobile devices for communication and mobile commerce. These direct relationships were not previously found in any other study related to mobile technology. Thus, these findings will contribute to the study of mobile technology and retail industry, especially when considering that fashion/brand leadership needs to be taken into account as a critical antecedent variable for understanding contemporary young consumers' perception of and attitudes toward using mobile devices.

\section{IMPLICATIONS FOR PRACTICE}

Our research findings offer some pragmatic implications for the marketers and retailers that have already adopted or are considering adopting mobile technology as additional channels to reach out to their customers. The Gen Y consumers have been identified as one of the most 
influential segments of the mobile industry due to their heavy use of these technologies (Lenhart et al., 2010). Their personal traits, such as significant high-technology involvement, higher predilection toward experimentation or trying new things, and stronger fashion/brand leadership, should be considered when developing mobile marketing strategies targeted for young adult consumers. Mobile retailers and marketers should look for these key personality traits because the individuals possessing these characteristics would be more inclined to be opinion leaders or innovators within their communities. In addition, these characteristics of Gen Y consumers may positively impact buzz marketing, that is, the favorable word-ofmouth impression generated among users/consumers based on their perceptions of innovativeness and opinion leaders.

Fashion/brand leadership displayed both direct and indirect impact on most endogenous variables in the proposed model. Ubiquitous use of mobile devices by young adult consumers as a means of social connectedness (Kolsaker \& Drakatos, 2009) and to expand social relationships (Pertierra, 2005) are deemed closely related to their fashion/brand leadership embodied in the visible, social use of the devices in public. Thus, it may be helpful for mobile marketers and retailers to adopt this construct to examine how mobile device use impacts the consumers' establishing and/or maintaining brand loyalty toward certain mobile device brands or mcommerce applications.

\section{LIMITATIONS AND SUGGESTIONS FOR FUTURE RESEARCH}

Several limitations of the study should be noted. First, some important variables are not integrated into the conceptual model. For example, possible predictor variables that may significantly influence consumers' attitude toward using mobile devices include trust (Gefen, Karahanna, \& Straub, 2003; Pennington, Wilcox, \& Grover, 2003) and privacy concerns (Dinev \& Hart, 2005). In addition, other gratification factors, such as a more diverse sample of the same cohort (i.e., ethnic background, other regions of the world, or social and economic status), may grant an opportunity to provide deeper understanding among this Gen Y consumer segment around the globe. In addition, future research may expand the present study using other generational cohorts (e.g., baby boomers, Gen X, Gen Z) throughout the USA to provide characteristics of the cohorts and their beliefs about and attitudes toward $\mathrm{m}$-commerce, which can assist in developing effective marketing strategies for the mobile retail industry.

Although it was not hypothesized in the present study, our results showed that there was a more dominant impact of perceived usefulness of the mobile devices for communication purposes as compared to perceived enjoyment on the attitude toward using mobile devices for communication purposes. This finding is contrary to the previous findings (e.g., Kim et al., 2009; van der Heijden, 2004) on the dominance of perceived enjoyment over perceived usefulness in influencing one's attitude toward the information system. This finding raises an opportunity for future research to investigate the relative impact of the TAM's perception variables in various retail or IT settings. 


\section{ENDNOTE}

1. We adopted a newer categorization of the generational cohort in the present paper. The Gen X refers to the individuals born between 1965 and 1976, Gen Y to those born between 1977 and 1995, and Gen Z to those born between 1996 and 2005 (Yan, 2006). It should be noted that another school of thought identified the millennials as a generational segment consisting of individuals born between 1982 and 2004, which encompasses most of Gen Y and Gen Z populations (Strauss \& Howe, 2010).

\section{REFERENCES}

Adweek. (2012, February 10). Data points: An app for that. Retrieved November 1, 2012, from www.adweek.com/news/technology/app-138200

Agarwal, R., \& Karahanna, E. (2000). Time flies when you're having fun: Cognitive absorption and beliefs about information technology usage. MIS Quarterly, 24, 665-694.

Agarwal, R., \& Prasad, J. (1998). A conceptual and operational definition of personal innovativeness in the domain of information technology. Information Systems Research, 9(2), 204-215.

Ajzen, I., \& Fishbein, M. (1980). Understanding attitudes and predicting social behavior. Englewood Cliffs, NJ, USA: Prentice-Hall.

Al-Gahtani, S. S., \& King, M. (1999). Attitudes, satisfaction and usage: Factors contributing to each in the acceptance of information technology. Behavior and Information Technology, 18(4), 277-297.

Altuna, O. K., \& Konuk, F. A. (2009). Understanding consumer attitudes toward mobile advertising and its impact on consumers' behavioral intentions: A cross-market comparison of United States and Turkish consumers. International Journal of Mobile Marketing, 4(2), 43-51.

Balabanis, G., \& Reynolds, N. L. (2001). Consumer attitudes towards multi-channel retailers' web-sites: The role of involvement, brand attitude, Internet knowledge and visit duration. Journal of Business Strategies, 18(2), 105-131.

Ball-Rokeach, S. J., \& DeFleur, M. L. (1976). A dependency model of mass media effects. Communication Research, 3(1), 3-21.

Bigné, E., Ruiz, C., \& Sanz, S. (2007). Key drivers of mobile commerce adoption: An exploratory study of Spanish mobile users. Journal of Theoretical and Applied Electronic Commerce Research, 2(2), 48-60.

Blumler, J. G., \& Katz, E. (1974). The uses of mass communications: Current perspectives on gratifications research. Beverly Hills, CA, USA: Sage.

Burns, E. (2005, August 29). Teen, college students are most active cell phone users. Retrieved March 14, 2011 , from http://www.clickz.com/clickz/news/1711408/teen-college-students-are-most-active-cell-phone-users

Byun, S.-E., \& Sternquist, B. (2011). Fast fashion and in-store hoarding: The drivers, moderator, and consequences. Clothing and Textiles Research Journal, 29(3), 187-201.

Celsi, R., \& Olson, J. C. (1988). The role of involvement in attention and comprehension process. Journal of Consumer Research, 15(2), 210-224.

Childers, T. L., Carr, C. L., Peck, J., \& Carson, S. (2001). Hedonic and utilitarian motivations for online retail shopping behavior. Journal of Retailing, 77, 511-535.

Chiu, C. M., Huang, H. Y., \& Yen, C. H. (2010). Antecedents of trust in online auctions. Electronic Commerce Research and Applications, 9, 148-159.

Cho, S., \& Workman, J. (2011). Gender, fashion innovativeness and opinion leadership, and need for touch: Effects on multi-channel choice and touch/non-touch preference in clothing shopping. Journal of Fashion Marketing and Management, 15(3), 363-382.

Chua, A. Y. K., Goh, D. H.-L., \& Lee, C. S. (2012). Mobile content contribution and retrieval: An exploratory study using the uses and gratifications paradigm. Information Processing and Management, 48, 13-22. 
Cronbach, L. J., \& Meehl, P. E. (1955). Construct validity in psychological tests. Psychological Bulletin, 52 , 281-302.

Cross-Bystrom, A. (2010, August 20). What you need to know about Generation Z. Retrieved March 3, 2011, from http://www.imediaconnection.com/content/27425.asp

Davis, F. D. (1989). Perceived usefulness, perceived ease of use and user acceptance of information technology. MIS Quarterly, 13(3), 319-340.

Dickerson, M. D., \& Gentry, J. W. (1983). Characteristics of adopters and non-adopters of home computers. Journal of Consumer Research, 10(2), 225-235.

Dinev, T., \& Hart, P. (2005). Internet privacy concerns and social awareness as determinants of intention to transact. International Journal of Electronic Commerce, 10(2), 7-29.

Ehret, J. (2011, July 6). Marketing to Gen Z-Teens. Retrieved November 11, 2011, from http://themarketingspot.com/2011/07/marketing-to-gen-zteens.html

Favell, A. (2011). Global mobile statistics 2011. Retrieved March 3, 2011, from http://mobithinking.com

Fiore, A. M., Jin, H.-J., \& Kim, J. (2005). For fun and profit: Hedonic value from image interactivity and responses toward an online store. Psychology and Marketing, 22(8), 669-694.

Fiore, A. M., \& Kim, J. (2007). An integrative framework capturing experiential and utilitarian shopping experience. International Journal of Retail and Distribution Management, 35(6), 421-442.

Fishbein, M., \& Ajzen, I. (1975). Belief, attitude, intention, and behavior. Reading, MA, USA: Addison-Wesley.

Gao, T., Sultan, F., \& Rohm, A. (2010). Factors influencing Chinese youth consumers' acceptance of mobile marketing. Journal of Consumer Marketing, 27(7), 574-583.

Gefen, D., Karahanna, E., \& Straub, D. W. (2003). Trust and TAM in online shopping: An integrated model. MIS Quarterly, 27(1), 51-90.

Gentry, L., \& Calantone, R. (2002). A comparison of three models to explain shop-bot use on the web. Psychology \& Marketing, 19, 945-956.

Goldsmith, R., \& Hofacker, C. (1992). Measuring consumer innovativeness. Journal of the Academy of Marketing Science, 19, 209-221.

Hawes, J. M., \& Lumpkin, J. R. (1984). Understanding the outshopper. Journal of the Academy of Marketing Science, 12, 200-218.

Hirunyawipada, T., \& Paswan, A. K. (2006). Consumer innovativeness and perceived risk: Implications for high technology product adoption. Journal of Consumer Marketing, 23, 182-198.

Hoffman, D. L., \& Novak, T. P. (1996). Marketing in hypermedia computer-mediated environments: Conceptual foundations. Journal of Marketing, 60(3), 50-69.

Holbrook, M. B., \& Hirschman, E. C. (1982). The experiential aspects of consumption: Consumer fantasies, feelings, and fun. Journal of Consumer Research, 9(2), 132-140.

Huei, P. V. (2004). The study on the acceptance of wireless computing devices among consumers in Penang (Unpublished master's thesis). Nottingham Trent University, England.

International Telecommunication Union (2011). ICT Facts and Figures: The world in 2011. Retrieved November 13, 2012, from http://www.itu.int/ITU-D/ict/facts/2011/material/ICTFactsFigures2011.pdf

Isomursu, P., Isomursu, M., \& Leinonen, E. (2006). User involvement of different target groups in mobile context. Advances in Consumer Research, 7, 244-248.

Jayasingh, S., \& Eze, U. C. (2009). An empirical analysis of consumer behavior intention toward mobile coupons in Malaysia. International Journal of Business and Information, 4(2), 221-242.

Jiang, J. J., Hsu, M. K., Klein, G., \& Lin, B. (2000). E-commerce user behavior model: An empirical study. Human Systems Management, 19(4), 265-276.

Joseph, B., \& Vyas, S. J. (1984). Concurrent validity of a measure of innovative cognitive style. Journal of the Academy of Marketing Science, 12, 159-175. 
Jun, J. W., \& Lee, S. (2007). Mobile media use and its impact on consumer attitudes toward mobile advertising. International Journal of Mobile Marketing, 2(1), 50-58.

Karaatli, G., Ma, J., \& Suntornpithug, N. (2010). Investigating mobile services' impact on consumer shopping experience and consumer decision-making. International Journal of Mobile Marketing, 5(2), 87-101.

Katz, E., \& Blumler, J. G. (1974). The uses of mass communications: Current perspectives on gratifications research. Beverly Hills, CA, USA: Sage.

Khare, A., Singh, S., \& Khare, A. (2010). Innovativeness/novelty-seeking behavior as determinants of online shopping behavior among Indian youth. Journal of Internet Commerce, 9(3-4), 164-185.

Kim, G. S., Park, S.-B., \& Oh, J. (2008). An examination of factors influencing consumer adoption of short message service (SMS). Psychology \& Marketing, 25(8), 769-786.

Kim, J., Fiore, A. M., \& Lee, H. H. (2007). Influences of online store perception, shopping enjoyment, and shopping involvement on consumer patronage behavior towards an online retailer. Journal of Retailing and Consumer Services, 14(2), 95-107.

Kim, J., Ma, Y.-J., \& Park, J. (2009). Are US consumers ready to adopt mobile technology for fashion goods? An integrated theoretical approach. Journal of Fashion Marketing and Management, 13(2), 215-230.

Kim, J., \& Park, J. (2005). A consumer shopping channel extension model: Attitude shift toward the online retailer. Journal of Fashion Marketing and Management, 9(1), 106-121.

Kincade, D. H., Kim, J., \& Gibson, F. (2010). Generational consumer segments and shopping process characteristics: Baby boomers and echo boomers with apparel product selection activities. Journal of Global Fashion Marketing, 1(1), 19-29.

Kline, R. B. (2004). Principles and practice of structural equation modeling (2nd ed.). New York, NY, USA: Guilford Press.

Ko, E., Kim, E. Y., \& Lee, E. K. (2009). Modeling consumer adoption of mobile shopping for fashion products in Korea. Psychology \& Marketing, 26(7), 669-687.

Kolsaker, A., \& Drakatos, N. (2009). Mobile advertising: The influence of emotional attachment to mobile devices on consumer receptiveness. Journal of Marketing Communications, 15(4), 267-280.

Ktoridou, D., Epaminondas, E., \& Kaufmann, H. R. (2008). Technological challenges and consumer perceptions of the use of mobile marketing: Evidence from Cyprus. International Journal of Mobile Marketing, 3(2), 34-43.

Kumar, A., \& Lim, H. (2008). Age differences in mobile service perceptions: Comparison of Generation Y and baby boomers. Journal of Services Marketing, 22(7), 568-577.

Kwon, H. S., \& Chidambaram, L. (2000). A test of the technology acceptance model: The case of cellular telephone adoption. In Proceedings of Hawaii International Conference on System Sciences, 34 (pp. 1-10). Maui, HI, USA: Computer Society Press.

Lenhart, A., Ling, R., Campbell, S., \& Purcell, K. (2010, April 20). Teens and mobile phones: Text messaging explodes as teens embrace it as the centerpiece of their communication strategies with friends. Retrieved February 27, 2012, from http://www.pewinternet.org/ /media/Files/Reports/2010/PIP-Teens-and-Mobile2010-with-topline.pdf

Leung, L. (2001). College student motives for chatting on the ICQ. New Media \& Society, 3, 483-500.

Leung, L., \& Wei, R. (2000). More than just talk on the move: Uses and gratifications of the cellular phone. Journalism \& Mass Communication Quarterly, 77, 308-320.

Lewis, W., Agarwal, R., \& Sambamurthy, V. (2003). Sources of influence on beliefs about information technology use: An empirical study of knowledge workers. MIS Quarterly, 27(4), 657-679.

Lu, J., Yao, J. E., \& Yu, C. (2005). Personal innovativeness, social influences and adoption of wireless Internet services via mobile technology. Journal of Strategic Information Systems, 14, 245-268.

Lumpkin, J. R. (1985). Shopping orientation of the elderly consumer. Journal of the Academy of Marketing Science, 13, 271-289. 
Maheswaren, D., \& Meyers-Levy, J. (1990). The influence of message framing and involvement. Journal of Marketing Research, 27, 361-367.

Maity, M. (2010). Critical factors of consumer decision-making on m-commerce: A qualitative study in the United States. International Journal of Mobile Marketing, 5(2), 87-101.

Mariga, J. R. (Ed.). (2003). Managing e-commerce and mobile computing technologies. West Lafayette, IN, USA: Purdue University.

McGuigan, J. (2005). Towards a sociology of the mobile phone. Human Technology: An Interdisciplinary Journal on Humans in ICT Environments, 1(1), 45-57.

Miller, C. M., McIntyre, S. H., \& Mantrala, M. K. (1993). Toward formalizing fashion theory. Journal of Marketing Research, 30, 142-157.

Nunnally, J. C., \& Bernstein, I. H. (1994). Psychometric theory (3rd ed.). New York, NY, USA: McGraw-Hill.

Nysveen, H., Pedersen, P. E., \& Thorbjornsen, H. (2005a). Intentions to use mobile services: Antecedents and cross-service comparisons. Journal of the Academy of Marketing Science, 33(3), 330-346.

Nysveen, H., Pedersen, P. E., \& Thorbjornsen, H. (2005b). Explaining intention to use mobile chat services: Moderating effect of gender. Journal of Consumer Marketing, 22(5), 247-256.

Oracle. (2011, April). Mobile trends: Consumer views of mobile shopping and mobile service providers (White paper). Retrieved on September 7, 2012, from http://www.oracle.com/us/industries/communications/oracle-atg-mobile-wp-345770.pdf

Pagani, M. (2004). Determinants of adoption of third generation mobile multimedia services. Journal of Interactive Marketing, 18(3), 46-59.

Park, J., \& Kim, J. (2007). The importance of perceived consumption delay in Internet shopping: Time-related information, time risk, attitude, and purchase intention. Clothing and Textiles Research Journal, 25(1), 24-41.

Peck, J., \& Childers, T. L. (2003). Individual differences in haptic information processing: The need for touch scale. Journal of Consumer Research, 30(3), 430-442.

Pennington, R., Wilcox H., \& Grover, V. (2003). The role of system trust in business-to-consumer transactions. Journal of Management Information Systems, 20(3), 197-226.

Pertierra, R. (2005). Mobile phones, identity, and discursive intimacy. Human Technology: An Interdisciplinary Journal on Humans in ICT Environments, 1(1), 23-44.

Phau, I., \& Teah, M. (2009). Young consumers' motives for using SMS and perceptions towards SMS advertising. Direct Marketing: An International Journal, 3(2), 97-108.

Sadia, S. (2011). User acceptance decision towards m-commerce technology: A study of user decision about acceptance of mobile commerce technology. Interdisciplinary Journal of Contemporary Research in Business, 2(12), 535-547.

Schumacker, R. E., \& Lomax, R. G. (2004). A beginner's guide to structural equation modeling (2nd ed.). Mahwah, NJ, USA: Lawrence Erlbaum Associates.

Shen, X., \& Chen, H. (2008). An empirical study of what drives consumers to use mobile advertising in China. In Proceedings of the 3rd International Conference on Grid and Pervasive Computing (pp. 158-163). Berlin, Germany: Springer.

Shtykh, R. Y., Jin, Q., Nakadate, S., Kandou, N., Hayata, T., \& Ma, J. (2009). Mobile SNS from the perspective of human self-extension. In I. Khalil (Ed.), Handbook of research on mobile multimedia (pp. 688-690). Hershey, PA, USA: IGI Global.

Stafford, T. F., Stafford M. R., \& Schkade, L. (2004). Determining uses and gratifications for the Internet. Decision Sciences, 35(2), 259-288.

Stayman, D. M., \& Batra, R. (1991). Encoding and retrieval of ad affect in memory. Journal of Marketing Research, 28(2), 232-239.

Strauss, W., \& Howe, N. (2010). Millennials: A portrait of generation next. Washington, DC: Pew Research Center. 
Taylor, A. S., \& Harper, R. (2001). Talking 'activity': Young people and mobile phones. In Proceedings of the CHI 2001 Workshop on Mobile Communications: Understanding Users, Adoption and Design (pp. 1-5). Seattle, WA, USA: ACM Press.

Thorbjornsen, H., Pedersen, P. E., \& Nysveen, H. (2007). “This is who I am”: Identity expressiveness and the theory of planned behavior. Psychology \& Marketing, 24(9), 763-785.

Totten, J. W., Lipscomb, T. J., Cook, R. A., \& Lesch, W. (2005). General patterns of cell phone usage among college students: A four-state study. Services Marketing Quarterly, 26(3), 13-39.

Tsang, M., Ho, S. C., \& Liang, T. P. (2004). Consumer attitudes toward mobile advertising: An empirical study. International Journal of Electronic Commerce, 8(3), 65-78.

van der Heijden, H. (2004). User acceptance of hedonic information systems. MIS Quarterly, 28, 695-704.

Venkatesh, V., \& Davis, F. D. (2000). A theoretical extension of the technology acceptance model: Four longitudinal field studies. Management Science 46(2), 186-204.

Venkatesh, V., Morris, M. G., Davis, G. B., \& Davis, F. D. (2003). User acceptance of information technology: Toward a unified view. MIS Quarterly, 27(3), 425-478.

Yan, S. (2006, December 8). Understanding Gen Y. Retrieved November 8, 2012, from http://www.oberlin.edu/stupub/ocreview/2006/12/08/features/Understanding_Generation_Y.html

Yaseen, G. S., \& Zayad, S. (2010). Exploring critical determinants in deploying mobile commerce technology. American Journal of Applied Sciences, 7(1), 120-126.

Yu, C. S., \& Tao, Y. H. (2009). Understanding business-level innovation technology adoption. Technovation, $29,92-109$.

\section{Authors' Note}

This research was financially funded in part by the Jerry Niles Faculty Research Grant awarded to the first author by the College of Liberal Arts and Human Sciences, Virginia Polytechnic Institute and State University, USA.

All correspondence should be addressed to

Jihyun Kim

Department of Apparel, Housing, and Resource Management

Virginia Polytechnic Institute and State University

240 Wallace Hall

Blacksburg, VA 24061 USA

jhkim@vt.edu

Human Technology: An Interdisciplinary Journal on Humans in ICT Environments

ISSN 1795-6889

www.humantechnology.jyu.fi 